\title{
BATI AVRUPA MEMLEKETLERİ HUKUKUNDA AKİT MEFHUMUNUN XX. ASIRDAKI TEKÂMÜLÜ (*)
}

Konferansi veren :

Prof. Francesko MESSINEO
Kisaltarak çeviren :

Doç. Dr. Halûk TANDOĞAN

XIX. astnn başında Fransız Medenî Kanununda ifadesini bulan ve başka bir çok memleketlerin, bilhassa lâtin memleketlerinin mevzuatına örnek teşkil eden akit telâkkisi, siyasî ve iktisadî sahadaki liberalist cereyanlara uygun olarak, içtimaî hayatı ferdiyetçi zaviyeden mütalâa eden görüşün izlerini taşımakta idi.

Fakat siyasî ve iktisadî şartlarda geçen asrın son yllanndan beri husule gelen tahavvüller neticesinde, akitler sahasında da ferdiyetçi ruhun yerini iç̧imaîlik ruhu aldı. Bu değişikliğin ârazını göstermek için kendi memleketimin akitler hukukunun tekâmülünü misal olarak alacağım; zira hem bu hukukun esaslarına daha yakından vakıfım, hem de 1942 tarihli İtalyan Medenî Kanunu ile konulan kaideler bahis mevzuu değişikliğin en yeni ve en mühim tezahürünü teşkil etmektedirler.

Bununla beraber, bu hareket aşağı yukan bütün batı Avrupada ayni şekilde görülmektedir; zira bunu tâyin eden tarihî ve sosyal âmiller birbirinin aynı veya benzer mahiyettedir; bilhassa arka arkaya iki dünya harbinin zuhur etmesi hareketi sür'atlendirmiştir. Bu devrede durmadan yeni siyasî ve iktisadî kuvvetler ortaya çıkmış ve bunlar akitler hukukunun tekâmülü üzerinde de tesirlerini göstermiştir.

Bir kelime ile akit artık sadece fertlerin irade serbestîsinin bir âleti olmaktan çıkmıs, onun ayni zamanda umumî menfaate uygun bir mahiyet taşıması gerekmeğe başlamıştır.

(*) Prof. Francesko Messineo tarafindan 16.11.1960 da Ankara Hukuk Fakültesinde verilmiş olan konferansın kısaltılmış tercümesidir. 
Bazı hukukçular akdin bu yeni karakterini belirtmek için «tanzim edilen» (réglé) veya «güdümlü» (dirigé) yahut «mecburî» (forcé) akitten bahsetmişler ve bu suretle Devletin müdahale temayülüne işaret etmek istemişlerdir.

Diğer bazı müellifler, akdin parçalanması (éclatement), ayrışıma uğraması (désintegration) gibi tâbirler kullanmışlardır. Bunu yaparken umumî iş mukavelesinde olduğu gibi tarafların iradesinin ikinci plâna itildiği, veya âdi kira veya ziraî hasılat kirasında müşahede edildiği gibi akdin hükümlerinin tarafların arzu veya önceden derpiş ettikleri zamanın ötesine taştığı veyahut da iş hukukunda rastlandığı gibi fiilî * münasebetlerin akde muadil sayıldığı halleri gözönünde tutmuşlardır.

Bu gibi âraz ve benzerleri karşısında bir kısım hukukçular akit mệfhumunun yerini, zaman ve mekân içinde istikrarlllığı ile kendini gösteren «müessese» (l'institution) mefhumunun ve plânlamanın alacağını düşünmektedirler.

Bundan başka, akitler sahasında tarafların iradesine konulan tahditlerin az çok daima ve bilhassa Fransız ihtilâline tekaddüm eden devrede mercut bulunmuş olduğu hatrrlanarak zamanımızdaki tahditlerin ehemmiyeti tebarüz ettirilmekte ve bunlarn bir sinff hukukunun ortaya çımasının neticesi olduğu söylenilmektedir.

Âzami fiat tesbitini zarurî kılan, malların, hususiyle istihlâk mallarmın istihsalindeki kifayetsizlik ve mesken buhranı; Devlet teşebbüslerinin ortaya çıkmasıyla bazı faaliyet sahalarııı hususî teșebbüslere menedilmesi; bazı akitlerin müddetinin kanunen tâyin edilmesi; ziraat işçilerinin işledikleri toprak dışına atılmayacakları hususunda emin olmak arzusu, sınaî işlerde akdî münasebetlerin ve patronun feshi ihbar hakkının tanzimi, asgarî ücretlerin tesbiti; gaz, elektrik, su tevzii, nakliye, telefon, radyo, televizyon gibi âmme hizmeti gören teşebbüslerin hizmetlerinden herkesi istifade ettirmesi zarureti; işsizlik tehlikesini önlemek endişesi; millî parayı değerini düșürecek spekülâtif manevralara karşı korunma ihtiyacı; akdì mes’uliyetten kurtulma şartlanını tahdit zarureti; tefecilerin menfaatlerine set çekme düşüncesi-gerçekte, bu eski zamanlarda da bahis mevzuu olmaktaydı; akdin muhtevasını tek taraflı olarak tesbit etmek isteyen iktisaden kuvvetli âkide karşıı zayıf olan tarafın himayesinin gerekmesi, edalar arasındaki fahiş nisbetsizliğin 
giderilmesi lüzumu; bütün bunlar sosyal ve iktisadî vakıalar sahasından akitler hukuku sahasına intikal ederek kanun vazınnı, hâkimi ve hatta tarafları tazyik etmekte gecikmediler.

- Gerçekte, iktisadî serbestî ve siyasî liberalizm prensiplerinin sukutu ve Devletin hususî iktisat sahasına ve umumiyetle hukukî teşkilâtlanmaya olan müdahalesinin artması karşısında bulunmaktayiz.

Daha önce bahsettiğimiz temayüller, murakabe edilen iktisat (économie contrôlée), veya programlı yahut plânlı iktisat (économie de programme ou économie planifiée) yahut da teşkilâtlanmış iktisat (économie organisée) adı altında Devletin ekonomik politikayı sevk ve idare etmesi şeklinde ifade olunabilir. Teşkilâtlanmış iktisadın süjeleri bir akdin tarafları olabilir.

Akit mefhumunun çehresini değiştiren âmiller yalnız iktisadî mahiyette değildir. Bazan objektif hüsnüniyetin ve âkitlerden birinin diğerine karşı gösterdiği itimadın himayesi gibi, geniş mânada ahlâki mahiyette saikler de, akde müdahale ve himayeye şayan olmayan akdî menfaatlerin reddedilmesi hususunda rol oynarlar. $\mathrm{Bu}$ hususta, akitlerde hakkaniyet icaplarmın yerine getirilmesi, kanuna karşı hilenin önlenmesi, muvazaa karşısında hüsnüniyetli üçüncü şahısların haklarının korunması, hatanın esaslı olmasıı için karşı âkitçe farkına varılmasının lâzım gelmesi gibi haller de misal olarak zikredilebilir. Bazan da hukuk tekniğinin icaplarını yerine getirmek bahis mevzuu olur; akdin feshedilebilmesi için onun ifa edilmeyen kısmının ehemmiyetli olması lüzumu; âkitlerden birinin mamelekî vaziyeti sarsılınca karşı âkide kendi edasını talik etmek salâhiyetinin tanınması; akdin taraflann iradesiyle tesbit edilmiş muhtevasının hâkim tarafından tamamlanması gibi.

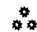

Bütün bu bahsettiklerimde, âkit tarafların iradesinin, hukuk nizamının yüksek iradesine tabi kılınmasının gittikçe barizleşmesini izah edebilecek kâfi derecede unsur bulunmaktadır.

Şimdi yeni içtimaî - hukuk dışı - görünüşlerin hukukî karşıliklarını göstermek lâzımdır.

Eski İtalyan MK. nun 1098 - 1130 ve 1209 - 1217 inci maddelerinin, yeni MK. un bunlara tekabül eden 1321 - 1369 uncu madde- 
leriyle basit bir mukayesesi neticesinde dahi, ilk bakışta, yeni kanunun ihtiva ettiği müesseselerin daha çeşitli ve tanzim tarzının daha ihtimamlı ve vazıh olması bir tarafa, istisnaî müesseseselerin normal müesseseler haline tahavvül ettiği görülür.

Yeni Kanun bundan başka tamamen yeni bazı prensipler getirmiştir :

a) Ezcümle akdin önceden taraflardan birinin yalnız başına tesbit ettiği umumî şartlar dairesinde teşekkülüne cevaz verilmiştir; umumî şartların önceden tesbiti yalnız seri halindeki, ayni mahiyette çok sayıdaki mübadele muamelelerinin (opérations de masse) yeknesak olarak tanzimini gerektiren hallere münhasır kalmamaktadır. Bununla beraber akdin umumî şartlar dairesinde teşekkülü, bu gibi iltihakî akitlerde taraflardan birinin elindeki inhisarı suiistimal etme temayülünde bulunduğu, âkitler arașinda iktisadî bakımdan eşitlik olmadığı gözönünde tutularak, iktisaden zayıf olan âkidin (yani müstehlikin ve umumî hizmetlerden faydalananm) iktisaden kuvvetli olan âkide karşı himayesi için gerekli tedbirler alınmak suretiyle kabul edilmiştir.

b) Yeni İtalyan Medenî Kanununda ve onu tamamlayan kanun larda rastlanan diğer bir yenilik, âmme hizmeti ifa eden ve bir inhisara sahip olan teşebbüslere yüklenen akit yapma mecburiyetidir; bu gibi teşebbüsler hizmetlerinden herkesi faydalandırmağa ve istihsal ettikleri malları herkese satmağa mecburdurlar; istedikleriyle akit yapıp istemedikleriyle yapmamakta serbest değildirler. Akit yapma mecburiyeti, bu mecburiyetin kendisine yüklendiği âkidin elinde bulundurduğu inhisar dolayısiyle, onun yaptığı hizmeti veya istihsal ettiği malları başkasından tedarik etme imkânının bulunmayışı dolayısiyle kabul edilmektedir. Bununla beraber, İtalyan MK. md. 2597 ye rağmen, müteşebbis, akit yapmağı reddettiği takdirde, hâkimin vereceği inşaî bir hükmün onun rızasınm yerine kaim olması esası tanınmamıştır. Diğer taraftan, akit yapma mecburiyeti olan hallerde, inhisara sahip olan âkide umumiyetle akdin umumî şartlarını önceden tesbit etmek hakkı tanınmaktadır.

Akit yapma mecburiyetine bağgl olan bir husus da şudur: Icrası idarî bir imtiyaz veya müsaadeye tabi hizmetler için idarì makamlar imtiyaz veya müsaadeyi verirlerken, bunu bazı şartlara tâbi kIlmaktadırlar; binnetice bu şartlar, hizmeti ifa eden teşebbüsün bundan faydalananlarla yaptığı akitlerin muhtevasına in'ikâs etmektedir. 
c) Diğer taraftan bazı edalar hakkında da sadece muayyen kimselerle akit yapmak mecburiyeti konulmakta; bu muayyen kimseler dışında kalanlarla akit yapmak menedilmektedir. Ezcümle bazı temsillere küçüklerin alınmasının, bazı maddelerin (meselâ -uyuşturucu maddelerin) herkese satılmasının menedilmesi gibi.

d) Şümulü çok geniş olan yeni bir kaide de, kanunî bazı şartlarnn ve Devletin tesbit ettiği azamî fiatların, tarafların akitte tâyin ettikleri şartların yerine kaim olacağının kabul edilmesidir; bu suretle ‘ tarafların rızasına bakılmaksızın, kanunî şartlar akdî şartların, resmî makamlarca tesbit edilen fiat taraflarca kararlaştırılanın yerini almaktadır.

$\mathrm{Bu}$ kaidenin menşeini, akdin muhtevasina teamülden doğan şartlarn da dahil eden Fransız Medenî Kanununda bulmak kabildir. Burada işaret edilmesi lâzım gelen cihet şudur ki, akit, taraflann önceden derpiş ettiklerini aşacak surette tadile uğramakta veya tamamlanmaktadır.

e) Yeni kanunda serbest rekabeti kolaylaştınıcı ve inhisara karşı cephe, alan bazı takyidler de bulunmaktadır. Ezcümle hizmet akitlerine bağlı rekabet memnuiyeti şartları zaman, mekân ve işin mahiyeti bakımundan tahdit edilmedikçe muteber değildirler. $\mathrm{Ge}-$ rek bu şartların, gerek bir ticarî işletmenin devrine bağlı rekabet memnuiyeti şartlarının müddeti beş seneden fazla olduğu takdirde bu müddet kanun hükmü icabı kendiliğinden beş seneye iner.

Bununla beraber yeni Kanunda inhisarî vaziyetleri himaye eden hükümler de yok değildir.

f) 1942 tarihli Medenî Kanun hususî akit tipleri, bilhassa âdi kira, ortakçllı, nakliye ve iş mukaveleleri sahasında da bir takım yenilikler getirmiştir. Bu yenilikler umumiyetle zayıf olan âkidin himayesi şeklinde tezahür etmekte ve zayłf olan âkit de umumiyetle borçlu olduğu cihetle, favor debitoris esası, yani borçlunun lehine hareket etme esası yeniden canlanmaktadır (*).

(*) Mütercimin notu: Prof. Messineo'nun iktisaden zayıf tarafın umumiyetle borçlu olduğu fikrine iştirak etmek biraz müşküldür; zira iktisaden zayıf tarafın himayesi umumiyetle karşllklı taahhütleri havi akitlerde bahis mevzuu olmaktadur; bu gibi akitlerde ise her iki taraf da hem alacakl hem de borçludur. 
Yeni Medenî Kanun ve Deniz Tícaret Kanunu, bundan başka eski Kanun zamanında isimsiz akit vasfını taşıyan bir çok mukaveleleri tanzim etmek suretiyle, evvelce teamüle ve taraflarn iradesine bağlı olan kaideler yerine kanunî kaideler koymuşlar, yeni iktisadì ihtiyaçlara uygun yeni hukukî vasıtalar yaratmışlardır.

Diğer taraftan, eski Medenî Kanun ve Ticaret Kanunundaki bazı hususî kaideler umumîleștirilmiş ve bütün akitlere teşmil edilmiştir.

Bazı akit tipleri, ezcümle kara, deniz ve havada nakliye mukaveleleri tanzim edilirken bu husustaki milletlerarası anlaşmalar gözönünde tutulmuștur.

Müşahede olunan diğer bir vakıa da akitler sahasında milletler üstü yeknesak kaideler vazetmek temayülüdür. Bu temayüle bir misal olmak üzere Roma'da Hususî Hukukun Tevhidi Enstitüsü’nün hazırladığı Menkul Satışı hakkındaki Kanun Tasansı zikredilebilir. Akitler hukukunun hiç olmazsa Küçük Avrupa çevresinde birleştirilmesi arzuya şayan olmakla beraber, bu mesele mevzuumuzun dişinda kalmaktadır.

İtalyan Medenî Kanununun akitler bahsi, faşist rejimi altında doğmus olmakla beraber, şimdiki demokrasi rejimine aykırı bir mahiyet taşıdığı söylenemez. Halen tanzim edici kuvvetlerini kaybetmiş olan korporatif esaslara vaki atıflar kanundan atılmış olduğu cihetle bu kanunun faşist kaynaklardan çıktığım beyan etmek, aşırı olur; kanunun müdahalelerden masun kalması faşist rejimi taraftarlarıın değil, fakat kanunu kaleme alanların liyakatından ileri gelmiştir. Akitler bahsinde sosyal vasıf taşıyan bazı kaide ve davranışlara rastlanmakla berber, bunların benzerleri tamamen demokratik esaslardan mülhem olan memleketlerde, meselâ Fransa'da da bulunmaktadır. Yeni İtalyan Medenî Kanununun antidemokratik olmadığının bir delili de, bu kanunun hiç bir hükmünün yeni Cumhuriyet Anayasasına aykırı olduğunun Anayasa Mahkemesi huzurunda şimdiye kadar ileri sürülmemiş olmasıdır.

\section{$\therefore$}

Şimdiye kadar yapmağa çalıştığım tahlillérden, muasır İtalyan hukukunda akitlerin umumî görünüşü hakkında bir netice çıarılmak istenilirse bilhassa üç husus üzerinde durulmalıdır : 
Bunlardan birincisi akit senbestîsi prensibinin sukutu, ikincisi âkitler arasında eşitlik prensibinin zayıflatılması, üçüncüsü fiilî akit mefhumunun tanınmasıdır. Bu üç husus 1865 tarihli eski Italyan MK. mer'iyette iken ortaya çıkan problemleri tamamen tadil etmektedir.

Evvelâ akit serbestîsi prensibi, gerek akdin muhtevasını tâyin etmek, gerek karşı âkidi seçmek, gerek akit yapıp yapmamakta serbest olmak bakımlarından pek çok tahdịde uğramıştır. Öyle ki bugün artık akit serbestîsinin kaide mi yoksa istisna mı olduğu hususunda tereddüt edilebilir.

Diğer taraftan, âkitlerden iktisaden zayıf olanı iktisaden kuvvetli olana karșı korumak için konulan hükümler, tarafların hukuken eşit muameleye tabi olması prensibini zayıflatmıştır.

Akit serbestîsinin tahditleri hakkındaki izahlanm artık «tanzim edilmiş akit» (contrat réglé) tabirinin kullanılmasının haklı olduğunu göstermektedir; bu tâbirle, hususi hukuka müteallik kanunların getirdikleri yenilikler ve âmme hukukunun âkitlerin iradesi üzerindeki in'ikâslan hulâsa edilmektedir.

Âmme hukukunun hususî hukuku istilâsı modern Devlete düşen görevlerin genişlemesinin neticesidir; buna muvazi olarak hususî mülkiyet hakkına konulan âmme hukuku takyidleri de artmaktadır; binaenaleyh bu, akdin çehresinin değişmesi vakıasını aşan bir meseledir.

Hukuk tekniği bakımından akit mefhumunun gerçek bir buhranı karşısında bulunulmaktadır; bu buhran, Devletin kısmen durdurmağa kısmen teşvik etmeğe çalıştığı iktisadî kuvvetlerin tazyiki altında gerek akitlere ait prensiplerde, gerek bunların tatbikatında kendini göstermektedir.

Modern akit her nekadar hukukî bakımdan bir dikta sayılamazsa da ve akit yapma mecburiyeti hallerini müstehlikler kütlesinin menfaatlerini korumak mülâhazasıyla izah mümkün ise de, umumî sartların önceden tesbiti akit mefhumunu gittikçe hareket serbestîsinin vasıtası olmaktan çıkarmaktadır.

Gerçekte akit ḋenilen bu hukukî mefhum iki kutup arasında, an'anevî irade kutbu ve iradeden tecerrüt ederek âkitleri ve hatta ekseriya içlerinden birini muayyen hükümlere tabi kılmak kutbu 
arasında sallanmaktadır. An'anevî akit mefhumu artık ayakta duramamakla beraber, cemiyet adına ferdi sıkıştıran ve ezen umumi menfaatın himayesi kıstasına başvurulmadıkça tatminkâr bir izah tarzı bulmak müskü̈ldür. Yalnız bu bakımdan gözden kaçırılmaması yerinde olan husus, umumî menfaatin kat'i olarak gerektirmediği hallerde istenilmeyen akde hüküm izafe edilmemesidir. 